\title{
Measuring Root Hydraulic Parameters of Container-grown Herbaceous and Woody Plants Using the Hydraulic Conductance Flow Meter
}

\author{
Lesley A. Judd ${ }^{1}$, Brian E. Jackson ${ }^{2,4}$, and William C. Fonteno ${ }^{3}$ \\ Department of Horticultural Science, North Carolina State University, 227 \\ Kilgore Hall, Campus Box 7609, Raleigh, NC 27695
}

Jean-Christophe Domec ${ }^{3}$ Bordeaux Sciences Agro, UMR 1391 ISPA, F-33170 Gradignan, France; Department of Forestry and Environmental Resources, North Carolina State University, Biltmore Hall, Campus Box 8001, Raleigh, NC 27695; and Nicholas School of the Environment, Duke University, Box 90328, Durham, NC 27708

Additional index words. root measurement, root resistance, water transport, wood substrates Abstract. Root hydraulic conductance and conductivity are physiological traits de-
scribing the ease with which water can move through the belowground vascular system
of a plant, and are used as indicators of plant performance and adaptability to a given
environment. The ability to measure hydraulic conductance of container-grown herba-
ceous and semiwoody plants with soft conductive tissue was tested using a hydraulic
conductance flow meter (HCFM). Although the HCFM is a hydraulic apparatus that has
been used on woody plants to measure hydraulic conductance of intact roots, it has never
been reportedly used on container-grown horticultural plants. Two herbaceous species,
Chrysanthemum L. and Solenstemon scutellarioides Thonn., were grown in containers
and hydraulic parameters were measured, including root conductance and root
conductivity, as well as physical traits such as stem diameter and dry root mass. The
HCFM was easily connected to intact roots even on herbaceous stems and was used to
determine hydraulic conductance and conductivity directly on container-grown plants
with minimal disturbance on the root system. Chrysanthemums, Buddleja davidii
Franch., and Hibiscus moscheutos L. were grown in three different substrates, and both
root mass and root hydraulic parameters were determined. Chrysanthemums showed
a positive response with increasing root hydraulic conductance with increasing root
mass. The substrates used in these studies only had an effect on root biomass of
chrysanthemums, but substrates had no differential effect on root hydraulic conductivity.

Water transport in plants is influenced by factors from the surrounding environment, as well as characteristics from the plant structure, root morphology, and anatomy. Over several decades, efforts have been made to better understand water uptake and transport in plants. The flow of water through plants has been commonly analyzed using the parameters of flow rate and the difference in water potentials between the rhizosphere, roots, and leaves. Alternative measures are hydraulic conductivity and hydraulic conductance (reciprocal of hydraulic resistance) (Passioura and Munns, 1984; Ramos and

Received for publication 5 Oct. 2015. Accepted for publication 31 Dec. 2015.

This article is a portion of a thesis submitted by Lesley A. Judd as required to fulfill degree requirements.

${ }^{1}$ Graduate Research Assistant.

${ }^{2}$ Associate Professor.

${ }^{3}$ Professor.

${ }^{4}$ Corresponding author. E-mail: brian_jackson@ ncsu.edu. hydraulic resistance; radial and axial pathways, apoplastic barriers, aquaporin activity, exo- and endodermis layers (presence and/or thickness), cortex presence, and/or thickness are all possible anatomical characteristics affecting plant hydraulic resistance (Miyamoto et al., 2001; Rieger and Litvin, 1999; Steudle, 2000; Tataranni et al., 2012).

It is well known that the hydraulic properties of roots vary with species and environmental conditions (Domec et al., 2004; Miyamoto et al., 2001), and these conditions can strongly influence root morphology and anatomy (Domec et al., 2010; Steudle and Peterson, 1998). Pine wood-based substrates generally involves the use of entire pine trees (i.e., bark, wood, cambium, and needles), which is a departure from using just pine bark (PB) in the greenhouse and nursery industry, and these wood-based substrates have been shown to have suitable physical and chemical properties (compared with PB or peat) while enhancing/increasing root growth (Gruda and Schnitzler, 2004a, 2004b; Jackson et al., 2010; Wright and Browder, 2005). With the reported increase in root growth of plants grown in wood substrates, measuring the hydraulic conductivity of root systems grown in substrates containing wood components may be insightful and help explain the growth increase/ substrate effect.

New instruments have been developed to measure hydraulic conductance/resistance with rapid water-flow measurements. One such device is the commercially available hydraulic conductance flow meter (Dynamax, Inc., Houston, TX). The HCFM can measure the hydraulic conductance of shoots and root systems by connecting the device to a branch, stem, or rootstock. To measure entire root systems, shoots are excised from the root system a few centimeters above substrate level and the rootstock or shoot stem is fitted with water-filled tubing of the HCFM. The HCFM uses constantly increasing pressure to cause water to flow into the attached root or shoot system, and this water flows in the opposite direction of normal transpiration (Tsuda and Tyree, 2000; Tyree et al., 1995).

The HCFM has mainly been used to measure stem, leaf, and root hydraulic conductivities on woody plants: Vitis vines (Vandeleur, 2007; Vandeleur et al., 2009, 2014), Prunus plants (Tataranni et al., 2012), and Tsuga trees (Domec et al., 2013). Using a device called the high pressure flow meter, root hydraulic conductance has been positively correlated to stem diameter (Tyree et al., 1995), root system surface area (Muhsin and Zwiazek, 2002; Tyree et al., 1995), and root length (Smith and Roberts, 2003). Rieger and Litvin (1999), using another method, measured $K_{r}$ of several plants with differing root anatomical features and found correlation was inversely related to both root diameter and cortex width. The question remains if there are possible correlations between increasing hydraulic conductance and increasing whole root system mass. 


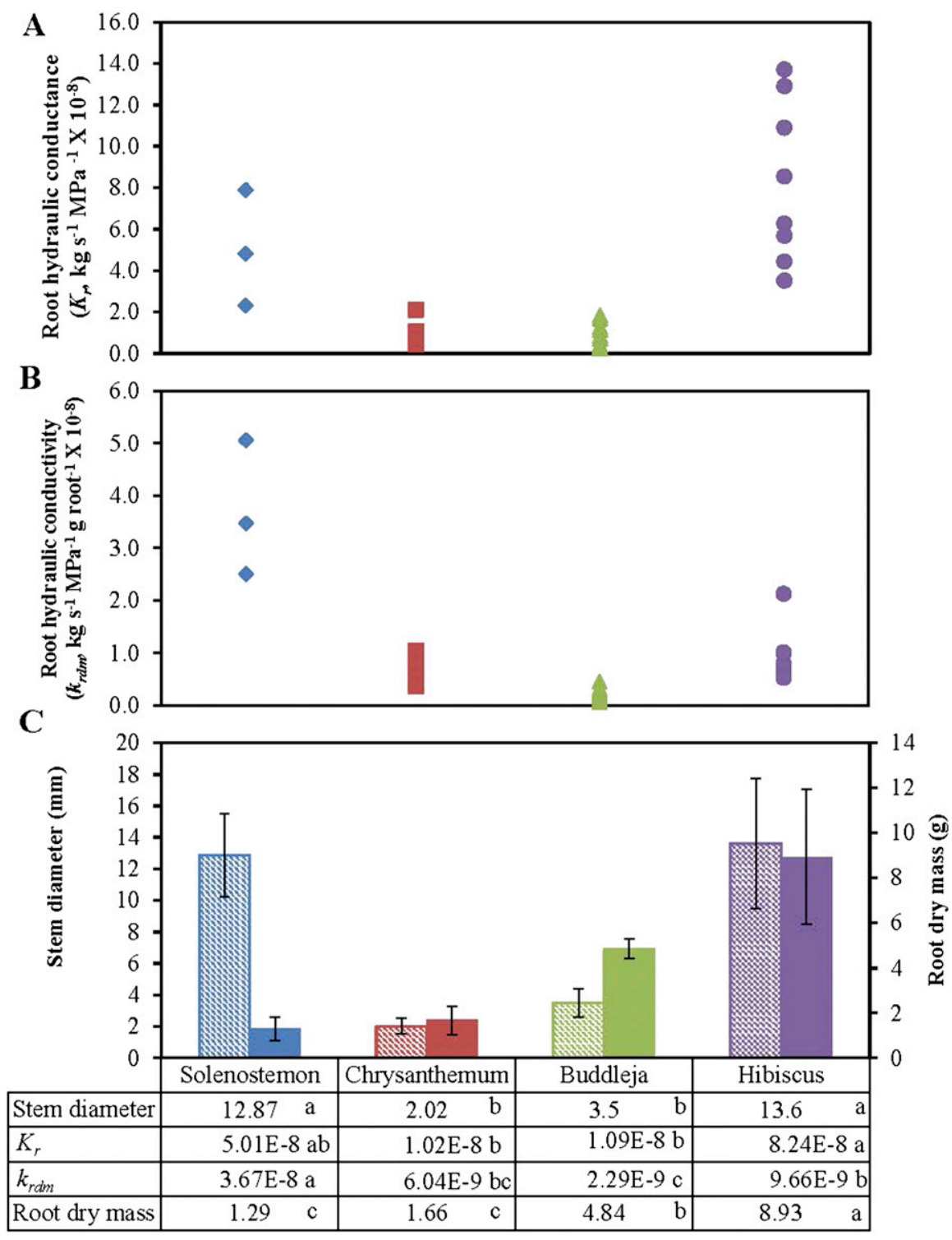

Fig. 1. (A) Root hydraulic conductance $\left(K_{r}\right)$ and (B) hydraulic conductivity $\left(k_{r d m}\right)$ for each replication of species grown in a control substrate. (C) Means of stem diameter (vertically shaded boxes) and root dry mass (solid boxes) for each species in control substrates, with error bars representing $95 \%$ confidence intervals. Control substrates are as follows: Solenostemon in $80 \%$ peat : $20 \%$ perlite, chrysanthemum in $80 \%$ peat : $20 \%$ perlite, buddleja and hibiscus in $100 \%$ pine bark (by volume). Means are shown for $K_{r}$, $k_{r d m}$, stem diameter, and root dry mass, and means separated across species (coleus $n=3$; chrysanthemum $n=3$; buddleja $n=9$; hibiscus $n=8$ ) using Tukey-Kramer adjustment for multiple comparisons at $P \leq 0.05$, means followed by the same letter are not significantly different.

The objectives of this study were to 1) explore the feasibility of measuring root hydraulic conductance and hydraulic conductivity of container-grown herbaceous and semiwoody plants using the HCFM; 2) investigate possible correlations between hydraulic conductivity and anatomical features, including whole root mass and plant stem diameter, and 3) investigate the potential influence of substrates containing wood components on plant root mass as measured by root hydraulic conductivity.

\section{Materials and Methods}

Operation of the HCFM. The HCFM is an apparatus designed to inject water into the base of either a root system, shoot system, or substrate in the containers, and then allowed to sit/saturate for $30 \mathrm{~min}$. This process was done to saturate the substrate (root ball) and pores around the roots, thus removing air from all pores and minimizing moisture content and pressure potential differences in the containers/root balls. After $30 \mathrm{~min}$ and while still saturated, plant stems were severed $3 \mathrm{~cm}$ above the substrate surface. The HCFM connection was immediately attached on the severed stem of the root ball (root system) and the HCFM began measuring root hydraulic conductance. Water was then systematically forced into the root system so as to not disrupt the roots but actually push the water throughout the root system, thereby obtaining a measure (conductivity) of the entire root mass at once. Root conductance, $K_{r}$, was computed from the slope of the linear regression between water flux (in kilograms per second) and pressure (range 0 to $0.55 \mathrm{MPa}$ ) supplied from the HCFM. The $K_{r}$ measurement was used in testing for possible correlations between root hydraulic conductance and root dry mass or stem diameter, respectively, to observe any effects of these covariables.

Chrysanthemum. Greenhouse experiments were conducted on Chrysanthemum 'Garden Alcala Red' grown in four different substrates: peat amended with $20 \%, 30 \%$, or $40 \%(\mathrm{v} / \mathrm{v})$ shredded pine wood (SPW) and a traditional 80 peat : 20 perlite (PL; by volume) substrate, which was used as a control. On 19 Dec. 2011, 8-year-old loblolly pine trees (Pinus taeda L.) were harvested in Chatham County, NC, at ground level, delimbed, and stored under shelter from weather. On 2 Jan. 2012, the delimbed pine logs were shredded in a wood shredder (Morbark ${ }^{\circledR}$ Wood Hog model 3800; Morbark, Winn, MI). The SPW was then processed in a hammer-mill through a $6.35-\mathrm{mm}$ screen (Meadows Mills, North Wilkesboro, NC) to produce SPW. The SPW had an initial moisture content after milling of $\approx 45 \%$. The material was then air-dried to a moisture content of $35 \%$, after which it was stored under shelter in unsealed $1.5 \mathrm{~m}^{3}$ bags until the initiation of this study. Drying the SPW was done to limit any chemical changes that may occur during storage $(\mathrm{pH}$ drift or other chemical change), which has been shown in unpublished studies by these authors to occur if stored after processing with moisture contents above $40 \%$.

The substrates were mixed on 4 June 2012; all substrates were tested for initial $\mathrm{pH}$ and then amended with dolomitic limestone at $3.86 \mathrm{~kg} \cdot \mathrm{m}^{-3}$ (No. 200; Mississippi Lime Company, Vicksburg, MS) for substrate $\mathrm{pH}$ to start at 5.4. On 5 June 2012, six greenhouse containers $(15.2 \mathrm{~cm}$ diameter; Dillen Products, Middlefield, $\mathrm{OH}$ ) were filled with each individual substrate to the top of the container and tapped three times, by lifting the containers $10 \mathrm{~cm}$ from a hard surface and dropping, to settle the substrate. One chrysanthemum plug (51-plug tray; C. Raker \& Sons, Inc, Litchfield, MI) was planted into the center of each container. 
Plants were randomized on a greenhouse bench in Raleigh, $\mathrm{NC}\left(35.78^{\circ} \mathrm{N} / 78.64^{\circ} \mathrm{W}\right)$, rectangular spacing was used with $7.62 \mathrm{~cm}$ between each container, and plants in each substrate were hand watered as needed depending on weather conditions and never showed symptoms of water stress. Plants were fertilized at each watering with $200 \mathrm{mg} \cdot \mathrm{L}^{-1}$ nitrogen derived from $20 \mathrm{~N}-4.4 \mathrm{P}-16.6 \mathrm{~K}$ (contained all micronutrients included; Peters Professional Peat-Lite Special; The Scotts Co., Marysville, $\mathrm{OH}$ ) and injected at 1:100 ratio by Dosatron injector [(D14MZ2); Dosatron International, Inc., Clearwater, FL].

On 6 July 2012, all container-grown chrysanthemums were removed from the greenhouse to a controlled temperature room and connected to the HCFM. After the measurements of $K_{r}$ were taken, the HCFM connection was removed and the root balls were then carefully washed and subsequently dried $\left(70^{\circ} \mathrm{C}\right.$ for $48 \mathrm{~h}$ ) and weighed (PG5002-S DeltaRange, Mettler Toledo, Columbus, $\mathrm{OH}$; resolution $\pm 0.01 \mathrm{~g}$ ) for biomass measurements.

Solenostemon. The second herbaceous growth study was conducted using coleus (Solenostemon scutellarioides 'Giant Exhibition') in the control mix used previously; 80 peat : 20 PL (by volume). The substrate was mixed on 2 July 2012, tested for initial $\mathrm{pH}$, and then amended with dolomitic limestone for $\mathrm{pH}$ adjustment at the same rate as previously stated for the chrysanthemum experiment. Coleus seeds (Fred C. Gloeckner Co., Harrison, NY) were sown into a 288plug tray $(1.5 \mathrm{~L} \times 1.5 \mathrm{~W} \times 3.5 \mathrm{H}-\mathrm{cm})$ containing (by volume) $65 \%$ peat : $20 \%$ PL : $15 \%$ vermiculite (Fafard Super Fine Germination Mix; Sungro Horticulture, Agawam, MA) in a greenhouse in Raleigh, NC, on 28 May 2012 and grown for 4 weeks. On 4 July 2012, containers (12.7 cm diameter; Dillen Products, Middlefield, $\mathrm{OH}$ ) were filled with the substrate as previously described and one coleus plug was planted into the center of each container. Plants were placed on greenhouse benches, and overhead watered and fertilized at each irrigation as described above. On 1 Aug. 2012, coleus plants were removed from the greenhouse into a controlled temperature room and the HCFM processes described above were conducted.

Semiwoody plants. Except where indicated, procedures were as described above. Greenhouse experiments were conducted with one liner of either hibiscus (Hibiscus moscheutos 'Luna Rose') or buddleja (Buddleja davidii 'Pink Delight'; 36-plug tray; C. Raker \& Sons, Inc, Litchfield, MI) grown in three substrates: 6-month aged PB at $100 \%$ as a control substrate and $\mathrm{PB}$ amended with $25 \%$ or $50 \%$ SPW (by volume). The SPW was from the same source as used and described in the chrysanthemum experiment. On 4 June 2012, substrates were mixed and tested for initial $\mathrm{pH}$. The substrates were then limed with dolomitic limestone at $3.6 \mathrm{~kg} \cdot \mathrm{m}^{-3}$ (No. 100; Rockydale Quarries Corporation, Roanoke, VA) for substrate $\mathrm{pH}$ to be between

Table 1. Physical properties substrates used in all experiments. ${ }^{z}$

\begin{tabular}{|c|c|c|c|c|}
\hline Substrate & $\begin{array}{c}\text { Container } \\
\text { capacity }^{\mathrm{y}}(\% \text { vol })\end{array}$ & $\begin{array}{l}\text { Air space }{ }^{x} \\
(\% \text { vol })\end{array}$ & $\begin{array}{c}\text { Total porosity } \\
(\% \text { vol })\end{array}$ & $\begin{array}{l}\text { Bulk density }^{\mathrm{v}} \\
(\mathrm{g} / \mathrm{cc})\end{array}$ \\
\hline & & Chrysanthemum & & \\
\hline $20 \% \mathrm{PL}^{\mathrm{u}}$ & $73.6 \mathrm{a}^{\mathrm{t}}$ & $14.0 \mathrm{~b}$ & $87.6 \mathrm{a}$ & $0.13 \mathrm{a}$ \\
\hline $20 \% \mathrm{SPW}^{\mathrm{s}}$ & $68.0 \mathrm{~b}$ & $22.0 \mathrm{aa}$ & $90.0 \mathrm{a}$ & $0.13 \mathrm{a}$ \\
\hline $30 \% \mathrm{SPW}^{\mathrm{r}}$ & $66.0 \mathrm{~b}$ & $18.0 \mathrm{ab}$ & $84.0 \mathrm{~b}$ & $0.13 \mathrm{a}$ \\
\hline $40 \% \mathrm{SPW}^{\mathrm{q}}$ & $66.1 \mathrm{~b}$ & 22.5 aа & $88.6 \mathrm{a}$ & $0.13 \mathrm{a}$ \\
\hline $20 \% \mathrm{PL}^{\mathrm{p}}$ & 73.5 & $\begin{array}{c}\text { Solenostemon } \\
14.5 \\
\text { Semiwoody plants }\end{array}$ & 88.0 & 0.11 \\
\hline $100 \% \mathrm{~PB}^{\circ}$ & $43.4 \mathrm{a}$ & $32.4 \mathrm{bb}$ & $75.8 \mathrm{a}$ & $0.20 \mathrm{a}$ \\
\hline $25 \% \mathrm{SPW}^{\mathrm{n}}$ & $33.2 \mathrm{~b}$ & $42.7 \mathrm{ab}$ & $75.9 \mathrm{a}$ & $0.18 \mathrm{~b}$ \\
\hline $50 \% \mathrm{SPW}^{\mathrm{m}}$ & $40.0 \mathrm{a}$ & $39.3 \mathrm{ab}$ & $79.3 \mathrm{a}$ & $0.18 \mathrm{~b}$ \\
\hline
\end{tabular}

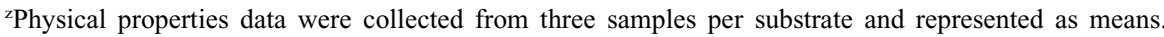
Analysis performed using the North Carolina State University Porometer method (Fonteno et al., 1995). ${ }^{y}$ Container capacity is (wet weight - oven dry weight) $\div$ volume of the sample.

${ }^{\mathrm{x}}$ Air space is the volume of water drained from the sample $\div$ volume of the sample.

wTotal porosity is container capacity + air space.

${ }^{v}$ Bulk density after forced-air drying at $105^{\circ} \mathrm{C}$ for $48 \mathrm{~h}$.

" $20 \% \mathrm{PL}=80 \%$ peat : $20 \%$ perlite (by volume).

${ }^{t}$ Means separated within column, across all substrates, within experiments using least significant difference, $P \leq 0.05$. Means followed by the same letter are not significantly different.

${ }^{s} 20 \%$ SPW $=80 \%$ peat : $20 \%$ shredded pine wood (by volume); SPW produced by shredding and hammermilling loblolly pine (Pinus taeda L.) logs through a 6.35-mm screen.

r $30 \% \mathrm{SPW}=70 \%$ peat : $30 \%$ shredded pine wood (by volume).

${ }^{\mathrm{q}} 40 \% \mathrm{SPW}=60 \%$ peat : $40 \%$ shredded pine wood (by volume)

${ }^{\mathrm{p}} 20 \% \mathrm{PL}=80 \%$ peat : $20 \%$ perlite (by volume).

${ }^{\circ} 100 \% \mathrm{~PB}=100 \%$ pine bark (by volume).

${ }^{\mathrm{n}} 25 \% \mathrm{SPW}=75 \%$ pine bark : $25 \%$ shredded pine wood (by volume)

${ }_{\mathrm{m}} 50 \% \mathrm{SPW}=50 \%$ pine bark : $50 \%$ shredded pine wood (by volume).

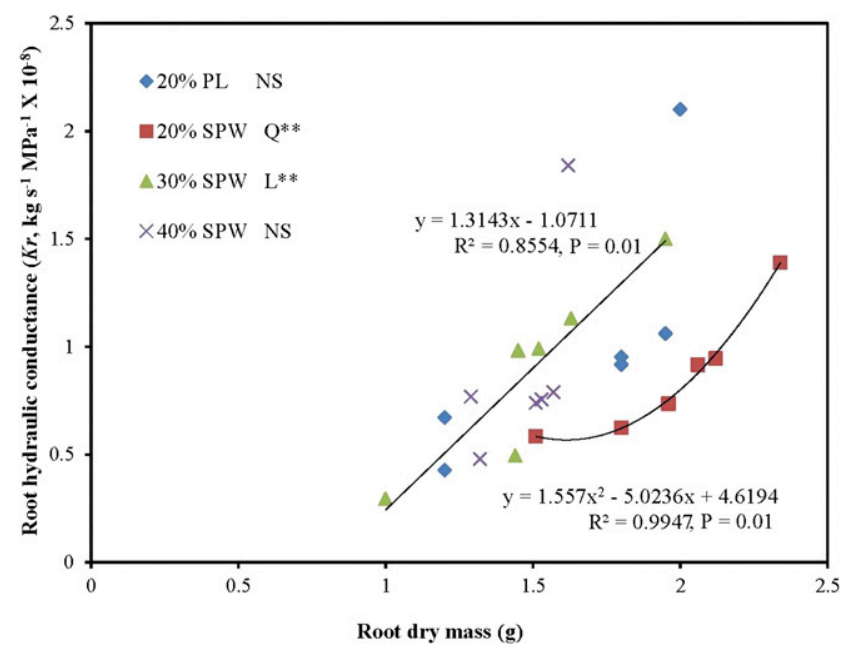

Fig. 2. Measurements of root hydraulic conductance of container-grown Chrysanthemum 'Garden Alcala Red' using the hydraulic conductance flow meter. Effect shown of root mass on chrysanthemum root hydraulic conductance when grown in substrates containing peat amended with $20 \%$ perlite (PL), $20 \%$, $30 \%$, or $40 \%$ shredded pine wood (SPW). Data was subjected to linear (L) and quadratic (Q) regression with NS, *, and ** representing no significant response, and significant effects when $P \leq 0.05$ and 0.01 , respectively.

5.2 and 5.4. On 5 June 2012, 12 nursery pots (3.8 L, $16.2 \mathrm{~cm}$ diameter; C300S, Nursery Supplies, Inc., Kissimmee, FL) were filled with each individual substrate and one liner of either buddleja or hibiscus was planted into the center of each container. There were nine replications of the buddleja plants and eight replications of the hibiscus plants for each substrate. Plants were randomized on a greenhouse bench and fertigated as described in the chrysanthemum experiment (Expt. 1).

On 10 July 2012, all container-grown buddleja and hibiscus were removed from the greenhouse to a temperature-controlled room as described above. The buddleja and hibiscus were then readied for root conductivity measurements and root dry mass measurements in the same manner as described in the previous studies.

Substrate physical properties. Physical properties, including air space (AS), container capacity (CC), total porosity (TP), and bulk density (BD), were determined on three replicate samples of each substrate in all experiments using the NCSU Porometer method as described by Fonteno et al. (1995). Samples of all substrates were collected when plants were potted for every 
experiment and used for substrate physical property analysis. These substrates were taken from the same source used to pot this experiment and therefore amended similarly.

Calculations of root conductivity and statistical analysis. Root conductance values $\left(K_{r}\right)$ were divided by root dry mass $(\mathrm{g})$ giving root hydraulic conductivity per unit mass $\left(k_{r d m}\right)$. Normalizing $K_{r}$ reduces effects directly due to the root system size (Tataranni et al., 2012), allowing for testing of substrate treatment effects and species differences. However, root conductance values do give an overall measure of the ability of the plant to take up water.

The effects of substrate on $k_{r d m}$, root dry mass, and stem diameter, and the effects of root dry mass and stem diameter on $K_{r}$ were tested based on an analysis of variance (SAS version 9.2; SAS Institute, Cary, NC). Means separation using least significant difference (LSD; $P \leq 0.05$ ) was used to compare means of $K_{r}, k_{r d m}$, and root dry mass across all substrates, and Tukey-Kramer adjustment for multiple comparisons $(P \leq 0.05)$ was used to compare means of $K_{r}, k_{r d m}$, stem diameter, and root dry mass across species for only the control mixes used. LSD $(P \leq 0.05)$ was used to compare means of the substrate physical properties for both experiments. Linear regression was analyzed to test for possible interactions between $K_{r}$ and root biomass or stem diameter.

\section{Results and Discussion}

Hydraulic conductance across species. All species grown in either the greenhouse (80\% peat : $20 \%$ PL) or nursery $(100 \% \mathrm{~PB})$ control substrate, and the root hydraulic conductances $\left(K_{r}\right)$, hydraulic conductivity $\left(k_{r d m}\right)$, stem diameter, and dry root mass were compared (Fig. 1). The mean $K_{r}$ of coleus and hibiscus were larger than that of buddleja and chrysanthemum plants $(P \leq 0.05$; Fig. 1$)$. The mean $k_{r d m}$ of coleus was larger than that of hibiscus, buddleja, and chrysanthemum. The stem diameter of coleus $(13 \mathrm{~mm})$ was about four times larger than that of the buddleja and chrysanthemum plants ( $3.5 \mathrm{~mm}$ and $2.0 \mathrm{~mm}$, respectively); however, the coleus and chrysanthemum plants had similar dry root mass $(1.29 \mathrm{~g}$ and $1.65 \mathrm{~g}$, respectively; Fig. 1). Hibiscus plants had a similar stem diameter compared with the coleus plants, and both these species also had larger and more variable $K_{r}$ compared with the other species.

Values of $K_{r}$ measured for coleus were similar to those of soybean $\left(10-30 \times 10^{-6}\right.$ $\mathrm{kg} \cdot \mathrm{s}^{-1} \cdot \mathrm{MPa}^{-1}$; Vandeleur et al., 2014) and maize $\left(1.25 \times 10^{-7} \mathrm{~kg} \cdot \mathrm{s}^{-1} \cdot \mathrm{MPa}^{-1}\right.$ per unit root length; Smith and Roberts, 2003). Mum $K_{r}$ were below these ranges; however, this could be a difference in stem/root thickness or less root surface area (Smith and Roberts, 2003). Buddleja and hibiscus $K_{r}$ measured with the HCFM had similar ranges compared with previous studies with the HCFM and woody plants. Hibiscus $K_{r}$ values were similar to measured root hydraulic conductances of elm
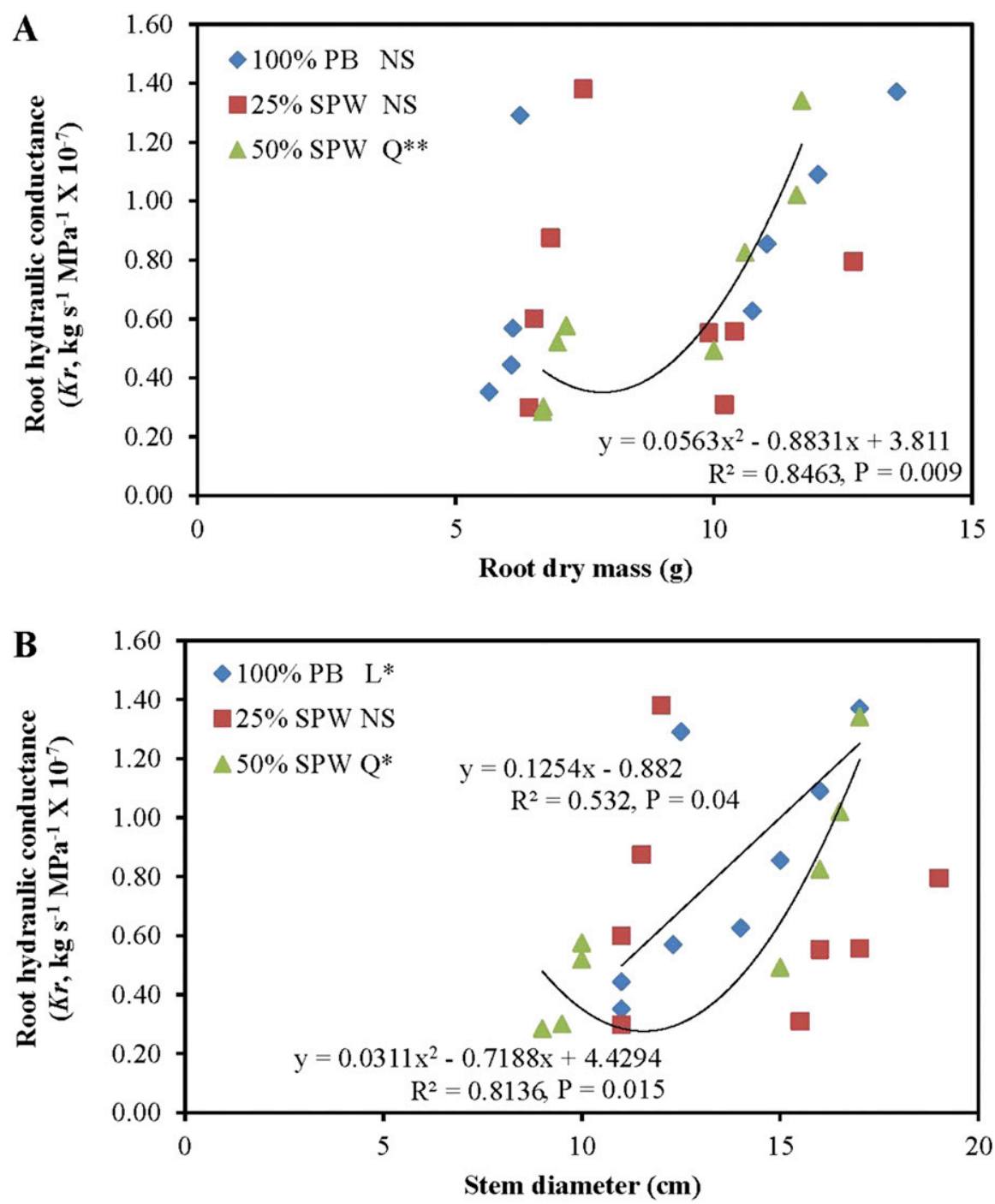

Fig. 3. Measurements of root hydraulic conductance $\left(K_{r}\right)$ of container-grown Hibiscus moscheutos ('Luna Rose') using the hydraulic conductance flow meter. Effect shown of (A) root mass or (B) stem diameter on hibiscus root hydraulic conductance when grown in substrates containing pine bark (PB) amended with $25 \%$ or $50 \%$ shredded pine wood (SPW). Data was subjected to linear (L) and quadratic (Q) regression with $\mathrm{NS}, *$, and $* *$ representing no significant response, and significant effects when $P \leq$ 0.05 and 0.01 , respectively.

seedlings $\left(0-8 \times 10^{-6} \mathrm{~kg} \cdot \mathrm{s}^{-1} \cdot \mathrm{MPa}^{-1}\right)($ Muhsin and Zwiazek, 2002) and Prunus plants (0-1.4 $\times$ $10^{-7} \mathrm{~kg} \cdot \mathrm{s}^{-1} \cdot \mathrm{MPa}^{-1}$ ) (Tataranni et al., 2012). Buddleja $K_{r}$ were below these ranges; however, like the mum plants this could be a difference in stem/root thickness or unseen anatomical resistances.

Chrysanthemum. Physical properties of these substrates show that $20 \%$ and $40 \%$ SPW substrates had higher AS than 20\% PL substrate, but these substrates were not significantly different in AS from 30\% SPW substrate (Table 1). The higher AS could account for an increase in root dry mass in the $20 \%$ SPW; other researchers have observed an increase in root growth with higher (around $20 \%$ to $25 \%$ by volume) air-filled porosity (Bunt, 1961; Strojny and Nowak, 2004).

Chrysanthemums grown in $20 \%$ SPW substrate had more root dry mass than plants grown in $30 \%$ or $40 \%$ SPW substrates, and were not different from plants grown in $20 \%$ PL substrate. There were no differences between the stem diameters of the plants among the substrates, and there were no differences in $K_{r}$ and $k_{r d m}$ among the plants grown in the four substrates. Chrysanthemums grown in the $30 \%$ SPW substrate had a positive linear response when $K_{r}$ was plotted against root dry mass (Fig. 2) and a quadratic response with chrysanthemums grown in $20 \% \mathrm{SPW}$. The positive correlation between root dry mass and $K_{r}$ coincides with our hypothesis that root hydraulic conductivity would increase with increasing root biomass.

Semiwoody plants. Physical properties showed $100 \%$ PB substrate had the highest BD compared with other substrates (Table 1). TP was not different among the substrates. The $100 \%$ PB substrate had low AS and high CC compared with $25 \%$ SPW substrate, and $100 \%$ PB substrate was not different from $50 \%$ SPW substrate in AS and CC (Table 1). All physical properties for the three substrates were in the acceptable range of 
properties (Bilderback et al., 2013) for barkbased woody plants, which could explain why there were no differences in either buddleja or hibiscus root dry mass between the substrates.

Both hibiscus and buddleja grown in the three PB substrates show no differences in root dry mass or $K_{r}$. Hibiscus plants grown in $50 \% \mathrm{SPW}$ had a positive quadratic response between $K_{r}$ and root dry mass (Fig. 3A), as well as stem diameter (Fig. 3B). Hibiscus plants grown in $100 \% \mathrm{~PB}$ had a positive linear response between $K_{r}$ and stem diameter (Fig. 3B).

\section{Conclusion}

Initial evidence indicates that the HCFM is capable of measuring hydraulic conductivity on the container-grown herbaceous and semiwoody plants tested. Root hydraulic conductances and conductivities measured in these studies are similar to previously documented work with nonhorticultural/ container crops. There was, however, quantified variability in conductance measurements within each plant species; this variability was considerable (three to five times) for some species. While there is no way to determine the effect of severing the shoots from the roots while measuring root hydraulic conductance, it was done within seconds of this procedure with seemingly little to no disturbance to the root system. High variability of root hydraulic conductivity was also reported by Vandeleur et al. (2009) and Vandeleur et al. (2014). Hydraulic conductance was correlated with dry root mass in only the chrysanthemum species.

More work is needed to better understand this within-species variation in hydraulic conductance. Since water movement through the plant is connected, from the root system to the leaves, a measure of hydraulic conductance through shoots or stomatal conductance of the leaves may provide a better picture of the complete water movement system through individual plants and provide the potential to lower the levels of variance in plants.

\section{Literature Cited}

Bilderback, T., C. Boyer, M. Chappell, G. Fain, D. Fare, C. Gilliam, B.E. Jackson, J. Lea-Cox, A.V. LeBude, A. Niemiera, J. Owen, J. Ruter, K. Tilt, S. Warren, S. White, T. Whitwell,
R. Wright, and T. Yeager. 2013. Best management practices: Guide for producing nursery crops. 3rd ed. Southern Nurserymen's Assoc., Acworth, GA

Bunt, A.C. 1961. Some physical properties of pot plant composts and their effect on plant growth. Plant Soil 15:13-24.

Cochard, H., R. Martin, P. Gross, and M.B. BogeatTriboulot. 2000. Temperature effects on hydraulic conductance and water relations of Quercus robur L. J. Expt. Bot. 51:1255-1259.

Domec, J.-C., L.N. Rivera, J.S. King, I. Peszlen, F. Hain, B. Smith, and J. Frampton. 2013. Hemlock woolly adelgid (Adelges tsugae) infestation affects water and carbon relations of eastern hemlock (Tsuga canadensis) and Carolina hemlock (Tsuga caroliniana). New Phytol. 199:452-463.

Domec, J.-C., K. Schafer, R. Oren, H.S. Kim, and H.R. McCarthy. 2010. Variable conductivity and embolism in roots and branches of four contrasting tree species and their impacts on whole-plant hydraulic performance under future atmospheric $\mathrm{CO}_{2}$ concentration. Tree Physiol. 30:1001-1015.

Domec, J.-C., J.M. Warren, F.C. Meinzer, J.R. Brooks, and J.R. Coulombe. 2004. Native root xylem embolism and stomatal closure in stands of Douglas-fir and ponderosa pine: Mitigation by hydraulic redistribution. Oecologia 141: $7-16$.

Fonteno, W.C., C.T. Hardin, and J.P. Brewster. 1995. Procedures for determining physical properties of horticultural substrates using the NCSU Porometer. Horticultural Substrates Laboratory, North Carolina State Univ., NC.

Gruda, N. and W.H. Schnitzler. 2004a. Suitability of wood fiber substrate for production of vegetable transplants I. Physical properties of wood fiber substrates. Sci. Hort. 100:309-322.

Gruda, N. and W.H. Schnitzler. 2004b. Suitability of wood fiber substrates for production of vegetable transplants II. The effect of wood fiber substrates and their volume weights on the growth of tomato transplants. Sci. Hort. 100:333-340.

Jackson, B.E., R.D. Wright, and M.C. Barnes. 2010. Methods of constructing a pine tree substrate from various wood particle sizes, organic amendments, and sand for desired physical properties and plant growth. HortScience 45:103-112.

Markhart, A.H., III, and B. Smit. 1990. Measurement of root hydraulic conductance. HortScience 25:282-287.

Miyamoto, N., E. Steudle, T. Hirasawa, and R. Lafitte. 2001. Hydraulic conductivity of rice roots. J. Expt. Bot. 52:1835-1846.

Muhsin, T.M. and J.J. Zwiazek. 2002. Ectomycorrhizas increase apoplastic water transport and root hydraulic conductivity in Ulmus americana seedlings. New Phytol. 153:153-158.

Passioura, J.B. and R. Munns. 1984. Hydraulic resistance of plants. II. Effects of rooting medium, and time of day, in barley and lupin. Austral. J. Plant Physiol. 11:341-350.

Ramos, C. and M.R. Kaufmann. 1979. Hydraulic resistance of rough lemon roots. Physiol. Plant. 45:311-314.

Rieger, M. and P. Litvin. 1999. Root system hydraulic conductivity in species with contrasting root anatomy. J. Expt. Bot. 50:201-209.

Smith, D.M. and J.M. Roberts. 2003. Hydraulic conductivities of competing root systems of Grevillea robusta and maize in agroforestry. Plant Soil 251:343-349.

Steudle, E. 2000. Water uptake by roots: Effects of water deficit. J. Expt. Bot. 51:1531-1542.

Steudle, E. and C.A. Peterson. 1998. How does water get through roots? J. Expt. Bot. 49:775788.

Strojny, Z. and J.S. Nowak. 2004. Effect of different growing media on the growth of some bedding plants. Acta Hort. 644:157-162.

Tataranni, G., G. Montanaro, B. Dichio, and C. Xiloyannis. 2012. Hydraulic conductivity in mycorrhisated Prunus plants. Acta Hort. 951:191-196.

Tsuda, M. and M.T. Tyree. 2000. Plant hydraulic conductance measured by the high pressure flow meter in crop plants. J. Expt. Bot. 51:823828.

Tyree, M.T. 2003. Hydraulic properties of roots, p. 125-150. In: E.J.W. Visser and H. de Kroon (eds.). Root ecology. Springer-Verlag, Berlin, DE.

Tyree, M.T., S. Patino, J. Bennink, and J. Alexander. 1995. Dynamic measurements of root hydraulic conductance using a high-pressure flowmeter in the laboratory and field. J. Expt. Bot. 46:83-94.

Vandeleur, R.K. 2007. Grapevine root hydraulics: The role of aquaporins. Univ. Adelaide, South Australia, PhD Diss.

Vandeleur, R.K., G. Mayo, M.C. Shelden, M. Gilliham, B.N. Kaiser, and S.D. Tyerman. 2009. The role of plasma membrane intrinsic protein aquaporins in water transport through roots: Diurnal and drought stress responses reveal different strategies between isohydric and anisohydric cultivars of grapevine. Plant Physiol. 149:445-460.

Vandeleur, R.K., W. Sullivan, A. Athman, C. Jordans, M. Gilliham, B.N. Kaiser, and S.D. Tyerman. 2014. Rapid shoot-to-root signaling regulates root hydraulic conductance via aquaporins. Plant Cell Environ. 37:520-538.

Wright, R.D. and J.F. Browder. 2005. Chipped pine logs: A potential substrate for greenhouse and nursery crops. HortScience 40:1513-1515. 